\title{
Using Magnetic Levitation to Separate Mixtures of Crystal Polymorphs
}

\section{Citation}

Atkinson, Manza B. J., David K. Bwambok, Jie Chen, Prashant D. Chopade, Martin M. Thuo, Charles R. Mace, Katherine A. Mirica, Ashok A. Kumar, Allan S. Myerson, and George M. Whitesides. 2013. "Using Magnetic Levitation to Separate Mixtures of Crystal Polymorphs." Angewandte Chemie 125(39): 10398-10401.

\section{Published Version}

doi:10.1002/ange.201305549

\section{Permanent link}

http://nrs.harvard.edu/urn-3:HUL.InstRepos:12361262

\section{Terms of Use}

This article was downloaded from Harvard University's DASH repository, and is made available under the terms and conditions applicable to Open Access Policy Articles, as set forth at http:// nrs.harvard.edu/urn-3:HUL.InstRepos:dash.current.terms-of-use\#OAP

\section{Share Your Story}

The Harvard community has made this article openly available.

Please share how this access benefits you. Submit a story.

\section{Accessibility}




\section{Using Magnetic Levitation to Separate Mixtures of Crystal Polymorphs}

Manza B.J. Atkinson, David K. Bwambok, Jie Chen, Prashant D. Chopode, Martin M. Thuo, Charles R. Mace, Katherine A. Mirica, Ashok A. Kumar, Allan S. Myerson, * and George M. Whitesides*

\section{$\underline{\text { Supporting Information }}$}

\section{Materials}

Sulfathiazole 2 was purchased from TCI America. Carbamazepine $\mathbf{3}$ was purchased from VWR International (Pittsburgh, PA). Compounds 5-methyl-2-[(2-nitrophenyl)amino]-3thiophenecarbonitrile (ROY) 1, trans-cinnamic acid 4, and ibuprofen ( $S$ - and $R, S$ - forms) 5 were purchased from Sigma Aldrich Company (St. Louis, MO). All compounds were used as received. All solvents used in this study were purchased from Sigma Aldrich Company (St. Louis, MO) and used as received.

The NdFeB magnets $(5 \mathrm{~cm} \times 5 \mathrm{~cm} \times 2.5 \mathrm{~cm})$ were purchased from K\&J Magnetics (www.kjmagnetics.com) and aligned on top of one another $4.5 \mathrm{~cm}$ apart within aluminum blocks. Calibrated density standards $\left( \pm 0.0002 \mathrm{~g} \mathrm{~cm}^{-3}\right.$ at $\left.23^{\circ} \mathrm{C}\right)$ were purchased from American Density Materials (Stauton, VA; www.densitymaterials.com). Spherical polymer samples were purchased from McMaster-Carr (www.mcmaster.com). Polystyrene microspheres with precisely defined radii were supplied by Duke Scientific Corporation (www.dukescientific.com), Polysciences, Inc. (www.polysciences.com), and Spherotech (www.spherotech.com). All other samples and reagents were purchased from Sigma Aldrich (Atlanta, GA) and used without further purification. 
Crystals of diffraction quality were characterized using single crystal X-ray diffraction, while crystals of poor diffraction quality, or a size too small for single crystal X-ray were characterized using Raman spectroscopy or powder X-ray diffraction (PXRD). Crystal data were collected on an APEX II DUO CCD diffractometer and an APEX II CCD diffractometer using $\operatorname{Mo} K_{\alpha}$ radiation $(\lambda=0.7107 \AA)$ at $100 \mathrm{~K}$. Raman spectra were obtained using a Raman Microprobe (Kaiser Optical Systems), equipped with a diode laser as the excitation source at 785 $\mathrm{nm}$, an optical light microscope (Leica), and a CCD camera. Images of crystals were taken using a Zeiss SteREO Discovery V8 microscope.

\section{Polymorphism}

Polymorphs can have differences in the following properties: density, $\rho{ }^{[1]}$ morphology; melting point; ${ }^{[2]}$ stability; ${ }^{[3]}$ solubility $;{ }^{[4]}$ color $;{ }^{[5]}$ sensitivity to detonation; ${ }^{[6]}$ solid-state reactivity ${ }^{[7]}$ absorptivity; ${ }^{[8]}$ electrical conductivity; ${ }^{[9]}$ magnetic susceptibility; ${ }^{[10]}$ tendency to charge triboelectrically; ${ }^{[11]}$ flowability; ${ }^{[12]}$ agglomeration; ${ }^{[13]}$ tableting, ${ }^{[14]}$ hygroscopicity, ${ }^{[15]}$ and index of refraction. ${ }^{[9 a, 16]}$

Polymorphism is of particular interest in the pharmaceutical industry. Drugs made from different polymorphic forms of the same active ingredient can vary in stability, solubility and dissolution rate and thus bioavailability. A well-known example of a drug that exhibits polymorphism is Ritonavir, a protease inhibitor. The appearance of a second, less soluble polymorph of Ritonavir resulted in the need to reformulate the drug two years after it was launched. ${ }^{[17]}$

\section{Methods}




\subsection{Preparation of crystal polymorphs}

$Y$ and YN polymorphs of ROY. ROY $(0.040 \mathrm{~g})$ was dissolved in $1 \mathrm{~mL}$ of isopropanol and allowed to crystallize at room temperature. Yellow needles and prisms formed rapidly over a period of three to five minutes. For seeding experiments, single crystals of form Y isolated from MagLev, were placed in a solution containing $20 \mathrm{mg}$ of ROY dissolved in $3 \mathrm{~mL}$ of ethanol (200 proof) after hot filtration. Product crystals were left to crystallize upon cooling to room temperature for a period of 24 hours.

Polymorphs II and IV of sulfathiazole. Sulfathiazole, $(0.020 \mathrm{~g})$ was dissolved in $2.5 \mathrm{~mL}$ of ethanol and left to crystallize upon cooling of solvent at room temperature. Crystals formed over a period of twenty-four hours. For seeding experiments, single crystals of form II isolated from MagLev, were placed in a solution containing $20 \mathrm{mg}$ of sulfathiazole dissolved in $2 \mathrm{~mL}$ of nitromethane after hot filtration. Product crystals were left to crystallize upon cooling to room temperature for a period of one hour.

$\alpha$ - and $\beta$-forms of trans-cinnamic acid. trans-Cinnamic acid $(0.250 \mathrm{~g})$ was dissolved in $1 \mathrm{~mL}$ of ethanol (200 proof), and left to crystallize at room temperature. Curved needles and blocks formed over a period of five minutes.

Polymorphs II and III of carbamazepine. Carbamazepine $(0.020 \mathrm{~g})$ was dissolved in $3 \mathrm{~mL}$ of toluene, and left to crystallize at room temperature. Long needles and prisms formed over a period of twenty-four hours.

R,S-Ibuprofen. Single crystals of RS-Ibuprofen were prepared by dissolving $40 \mathrm{mg}$ of solid in 2 $\mathrm{mL}$ of ethanol. The solution was allowed to evaporate at room temperature to afford single crystals of the racemate. 
S-Ibuprofen. Single crystals of S-Ibuprofen were prepared by gently heating $1 \mathrm{~g}$ of solid in 0.5 $\mathrm{mL}$ of diethyl ether in a closed $1.8 \mathrm{~mL}$ vial on a hot plate. The solution was then left on the hot plate, and crystallization occurred as the plate cooled to room temperature.

Figure S1. a) Molecular structure of ibuprofen. b) Photographs of single crystals of $R, S$ Ibuprofen and $S$-Ibuprofen levitating in an aqueous $0.55 \mathrm{M} \mathrm{MnCl}_{2}$ solution containing $0.25 \mathrm{M}$ sucrose and $1.0 \%$ Tween 20 .

a)<smiles>CC(C)Cc1ccc(C(C)C(=O)O)cc1</smiles>

b)

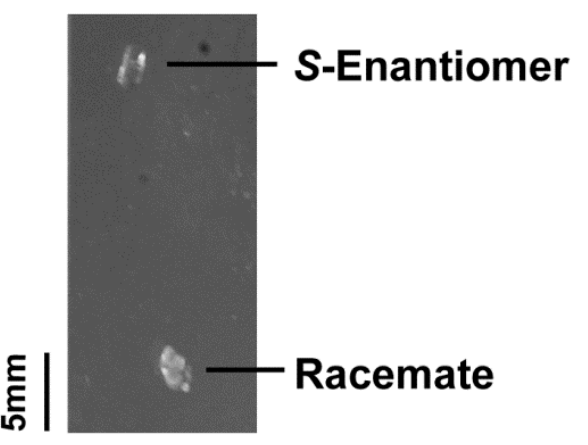




\subsection{MagLev Apparatus}

Figure S2. Photographs of components for isolating crystal polymorphs. a) A plastic cuvette composed of polymethyl methacrylate (PMMA). Holes of either $3 / 16$ " or $5 / 8$ " diameter were drilled approximately $2 \mathrm{~mm}$ from the bottom of the cuvette. Silicone rubber tubing is cut in 3 inch pieces and placed inside the holes of the cuvette. Five-minute epoxy is used to seal the tubing and cuvette. Luer locks are placed at the end of the tubes. Plastic syringes are connected to the Luer locks for extraction of the fluid. b) A cuvette holder made of transparent acrylic polymer. The acrylic block has a slit for the cuvette to slide into the center and a nylon screw to further secure the cuvette from moving. c) Complete assembly that includes syringes mounted on a microscopy stage. 
a)

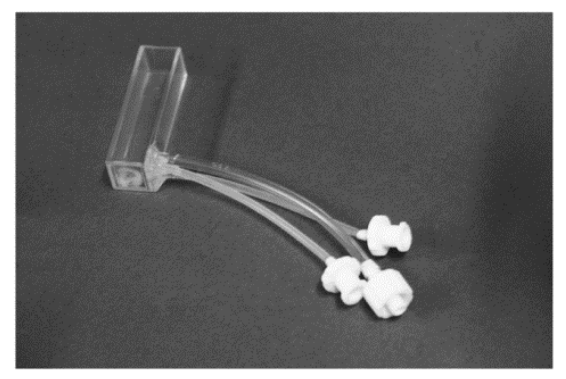

b)

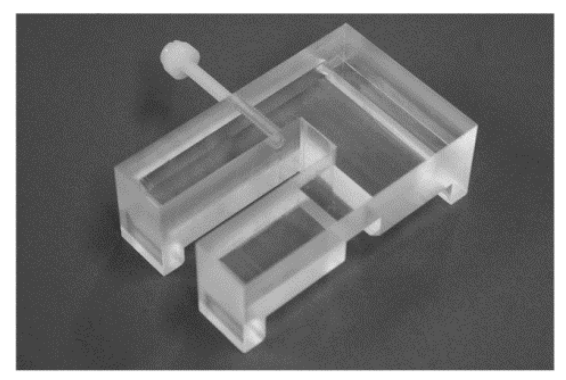

c)

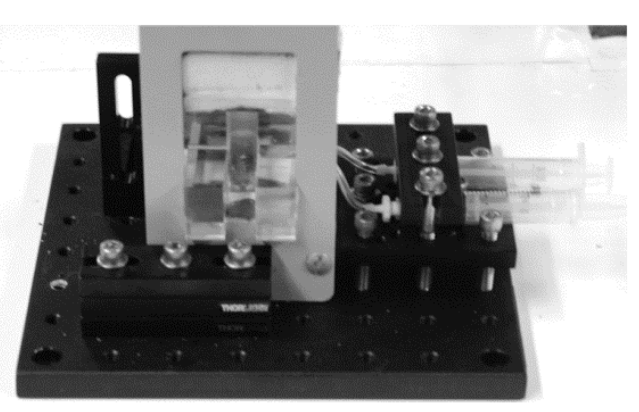


Figure S3. Isolating crystal polymorphs. (i) A syringe is used to withdraw the paramagnetic medium and the more dense population of crystals suspended within. (ii) As the first population of crystals from the paramagnetic medium is being removed, the less dense moves with the meniscus toward the bottom of the cuvette. The syringes were disconnected from the tubes and the contents were ejected into an empty container.

a)

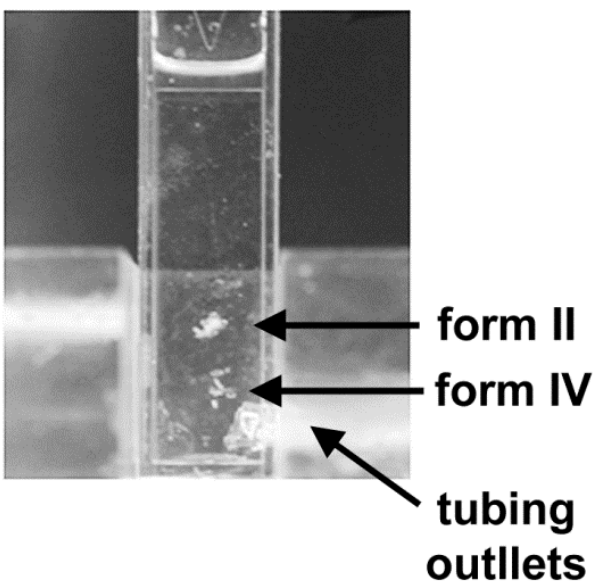

b)

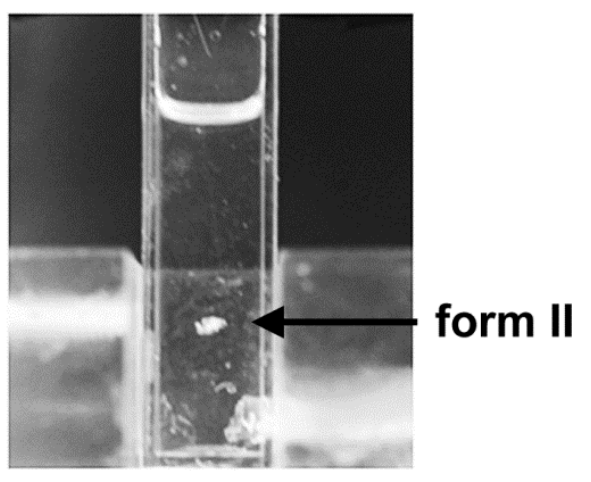


Figure S4. Photographs of seed crystals isolated from MagLev and products of seeded crystallizations of form Y of ROY 1, and form II of sulfathiazole, 2. The product of form Y of ROY increases in size $(\sim 2 \mathrm{x})$. The product crystals of sulfathiazole (form II), show nucleation on the surface of the seed crystals.

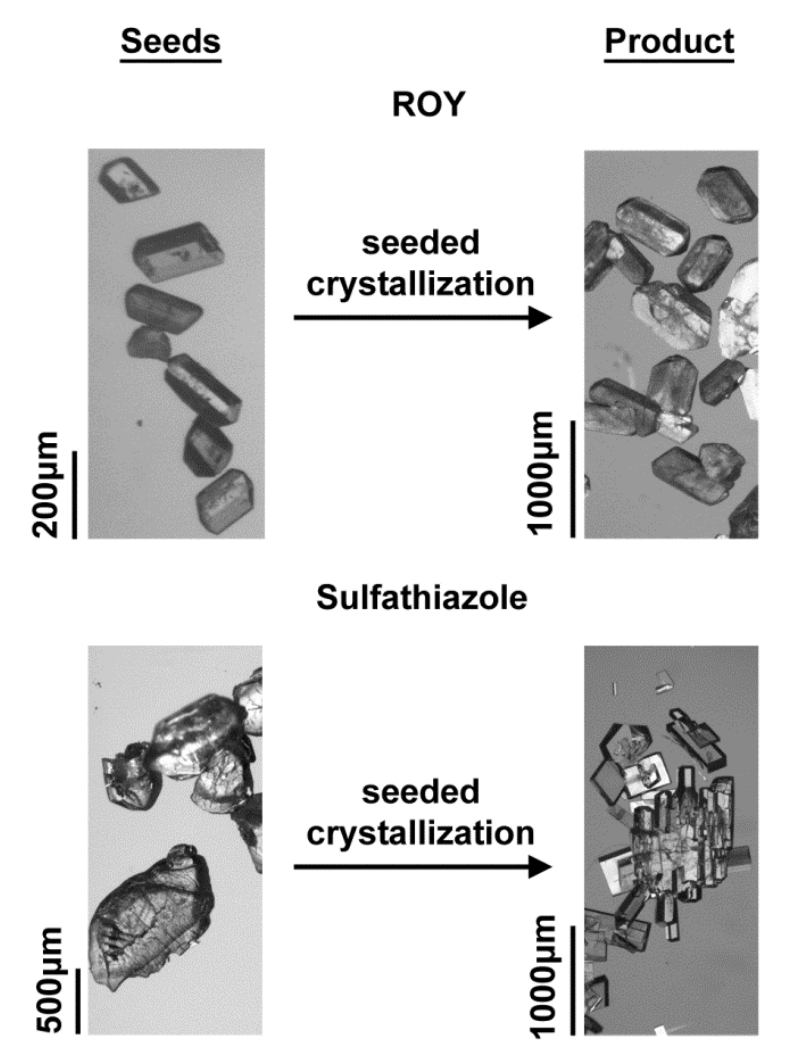




\section{X-ray Crystallographic Information}

Single crystals were taken from each experiment before and after levitation. The unit cell dimensions of each crystal were collected and used to confirm the polymorphic form. Equation 2 is used to determine if the unit cell parameters are significantly different before and after MagLev, where $\Delta$ is the difference between the two parameters and $\sigma_{1}$ is the standard uncertainty of the unit cell parameter of a crystal before levitation and $\sigma_{2}$ is the standard uncertainty of the

$$
\frac{\Delta}{\sqrt{\sigma_{1}^{2}+\sigma_{2}^{2}}} \geq 3
$$

unit cell parameter of a crystal after levitation. ${ }^{[18]}$ If the difference $(\Delta)$ between the unit cell parameters from Eq.(2), is more than three times the standard uncertainty of the difference, than the two unit cells are significantly different. In contrast, if the difference $(\Delta)$ between the unit cell parameters is less than three times the standard uncertainty of the difference, than the two unit cells are not significantly different. The density of the solids were calculated by incorporating the values obtained from the unit cell data into equation 3 as shown below, where $\rho$

is the density $\left(\mathrm{g} \mathrm{cm}^{-3}\right), M$ is the mass of a mole of molecules $(\mathrm{kg}), N_{\mathrm{A}}$ is Avogadro's number, $V$ is 


$$
\rho=\frac{M N_{A}}{V^{3} Z}
$$

the volume of the unit cell $\left(\mathrm{cm}^{3}\right)$, and $Z$ is the number of molecules per unit cell. ${ }^{[18]}$

\subsection{X-ray Crystallographic Tables}

Table S1. Unit cell values obtained from literature and average unit cell values from single crystal x-ray crystallography of seven crystals before levitation and after levitation in the paramagnetic medium. Quantitative differences between the average unit cell parameters before and after levitation are calculated by using the $3 \sigma$ rule as calculated from equation 2 . No value is significantly different owing to the fact that no value for each parameter is greater than three.

\begin{tabular}{|c|c|c|c|c|c|c|c|c|c|}
\hline Compound & Form & $\begin{array}{c}\text { Unit Cell } \\
\text { Experiment }\end{array}$ & a & b & c & $\alpha$ & $\boldsymbol{\beta}$ & $\gamma$ & $\mathbf{V}\left(\AA^{3}\right)$ \\
\hline \multirow{4}{*}{1} & \multirow{4}{*}{$\mathbf{Y}$} & Literature & $8.5001(8)$ & $16.413(2)$ & $8.5371(5)$ & 90 & $91.767(7)$ & 90 & $1190.5(4)$ \\
\hline & & Before MagLev & $8.494(7)$ & $16.08(1)$ & $8.501(6)$ & 90 & $91.36(3)$ & 90 & 1161(2) \\
\hline & & After MagLev & $8.477(6)$ & $16.036(7)$ & $8.486(4)$ & 90 & $91.28(3)$ & 90 & 1153(1) \\
\hline & & $3 \sigma$ test value & 2.064 & 2.699 & 1.82 & N/A & 1.835 & N/A & 2.36 \\
\hline \multirow{8}{*}{2} & \multirow{4}{*}{ II } & Literature & $8.235(4)$ & $8.550(4)$ & $15.558(8)$ & 90 & $93.67(1)$ & 90 & 1093.181 \\
\hline & & Before MagLev & $8.195(4)$ & $8.48(5)$ & $15.45(1)$ & 90 & $94.17(4)$ & 90 & $1078(1)$ \\
\hline & & After MagLev & $8.20(2)$ & $8.56(1)$ & $15.56(8)$ & 90 & $94.3(2)$ & 90 & $1090(8)$ \\
\hline & & $3 \sigma$ test value & 0.5008 & 1.391 & 1.354 & N/A & 0.5942 & N/A & 1.409 \\
\hline & \multirow{4}{*}{ IV } & Literature & $10.774(1)$ & $8.467(1)$ & 11.367(1) & 90 & $91.65(1)$ & 90 & 1036.507 \\
\hline & & Before MagLev & $10.78(1)$ & $8.480(2)$ & $11.395(4)$ & 90 & $91.62(2)$ & 90 & 1041(1) \\
\hline & & After MagLev & 10.81(1) & $8.498(9)$ & 11.41(1) & 90 & $91.75(5)$ & 90 & $1048(3)$ \\
\hline & & $3 \sigma$ test value & 1.469 & 1.797 & 1.342 & N/A & 2.278 & N/A & 1.639 \\
\hline \multirow{7}{*}{3} & \multirow{4}{*}{ II } & Literature & $35.454(3)$ & $35.454(3)$ & $5.253(1)$ & 90 & 90 & 120 & 5718.321 \\
\hline & & Before MagLev & $35.20(4)$ & $35.20(4)$ & $5.176(5)$ & 90 & 90 & 120 & $5555(18)$ \\
\hline & & After MagLev & $35.27(7)$ & $35.27(7)$ & $5.17(1)$ & 90 & 90 & 120 & $5579(34)$ \\
\hline & & $3 \sigma$ test value & 0.8747 & 0.8747 & 0.02111 & N/A & N/A & N/A & 0.03969 \\
\hline & \multirow{3}{*}{ III } & Literature & $7.534(1)$ & $11.150(2)$ & $13.917(3)$ & 90 & $92.94(4)$ & N/A & 1167.546 \\
\hline & & Before MagLev & $7.505(4)$ & $11.06(5)$ & 13.79(1) & 90 & 92.96(4) & 90 & $1143(1)$ \\
\hline & & After MagLev & $7.53(2)$ & 11.091(1) & $13.82(8)$ & 90 & $92.9(2)$ & 90 & $1153(8)$ \\
\hline
\end{tabular}




\begin{tabular}{|c|c|c|c|c|c|c|c|c|c|}
\hline & & $3 \sigma$ test value & 0.5008 & 1.391 & 0.9902 & N/A & 0.5942 & N/A & 1.409 \\
\hline \multirow{4}{*}{4} & \multirow{4}{*}{$\alpha$} & Literature & $5.582(2)$ & $17.671(4)$ & $7.735(2)$ & 90 & $96.49(2)$ & 90 & 758.087 \\
\hline & & Before MagLev & $5.547(9)$ & 17.51(3) & $7.70(1)$ & 90 & $96.24(1)$ & 90 & $743(4)$ \\
\hline & & After MagLev & $5.557(8)$ & $17.55(1)$ & $7.73(1)$ & 90 & $96.29(8)$ & 90 & $749(3)$ \\
\hline & & $3 \sigma$ test value & 0.7457 & 1.038 & 1.036 & N/A & 0.5726 & N/A & 0.9869 \\
\hline
\end{tabular}

\subsection{Raman Spectra}

Figure S5. Raman spectra before and after MagLev showing the characteristic stretches of a) form YN of ROY, b) $\beta$-trans-cinnamic acid, and (c) $S$ - and $R S$-Ibuprofen. The characteristic Raman shifts are similar before and after levitation showing that the polymorphs have the same form before and after MagLev. 
a)

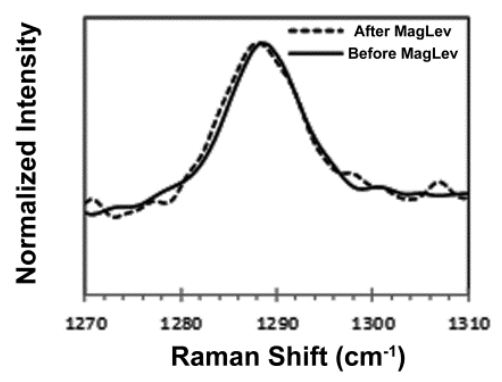

b)

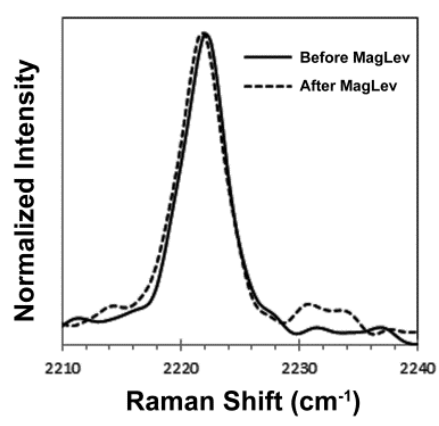

c)

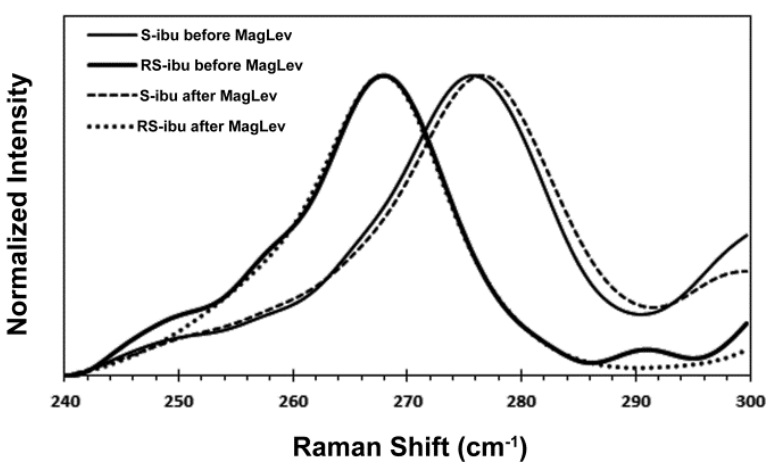

\subsection{Powder X-ray diffraction}

Figure S6. Powder X-ray diffraction patterns of trans-cinnamic acid (signature peaks are highlighted with an asterisk, *). a) The experimental PXRD of the $\beta$-polymorph (needle-like plates) of trans-cinnamic acid. b) The simulated PXRD pattern of $\beta$-polymorph of transcinnamic acid. The $\beta$-polymorph is confirmed as evidenced by the simulated pattern that matches with the experimental. 


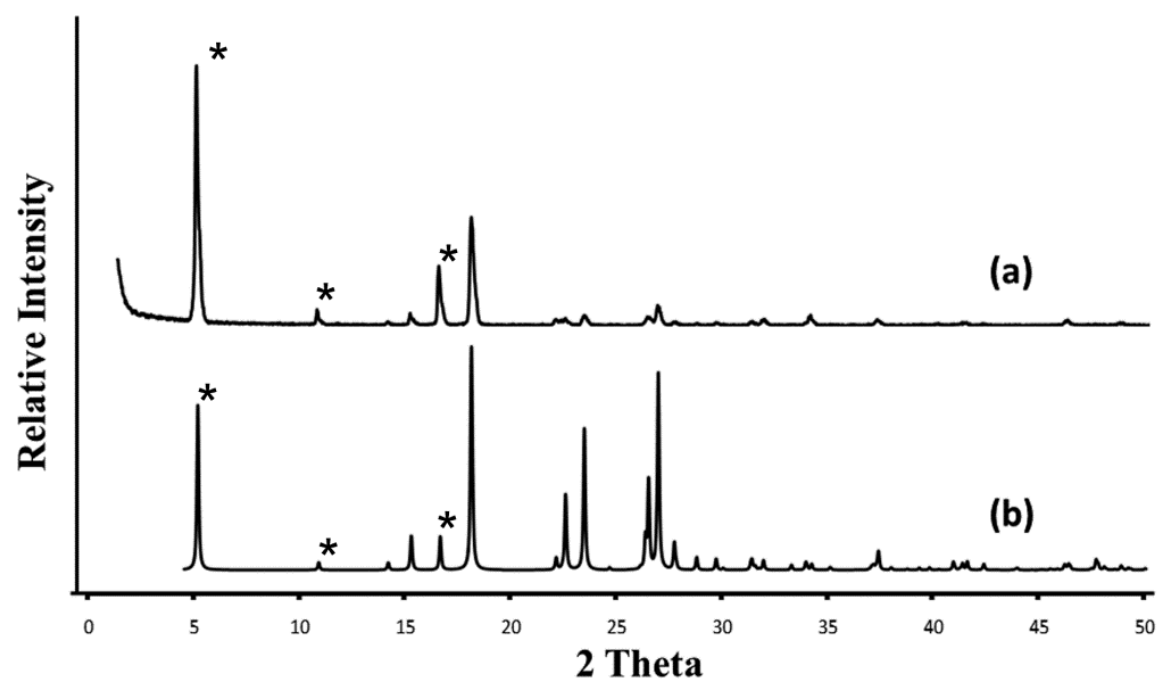

\subsection{Densities calculated from $X$-ray and MagLev}

Table S2. Average values (calculated from seven independent measurements) and the uncertainty in measurement of density of all solids. We calculated the densities of the crystals using calibration curves determined from levitation heights using density standards (i.e. glass, polymer beads) as previously reported. ${ }^{[19]}$ 


\begin{tabular}{|c|c|c|c|}
\hline Compound & Form & $\rho\left(\mathrm{g} / \mathrm{cm}^{3}\right) \mathrm{X}$-ray & $\rho\left(\mathrm{g} / \mathrm{cm}^{3}\right)$ MagLev \\
\hline \multirow{2}{*}{ ROY } & YN & $1.428^{[20]}$ & $1.372 \pm 0.020$ \\
\cline { 2 - 4 } & Y & $1.447^{[20]}$ & $1.450 \pm 0.006$ \\
\hline \multirow{2}{*}{ sulfathiazole } & II & $1.546^{[2]]}$ & $1.541 \pm 0.004$ \\
\cline { 2 - 4 } & IV & $1.600^{[21]}$ & $1.580 \pm 0.004$ \\
\hline \multirow{2}{*}{ trans-cinnamic acid } & $\alpha$ & $1.265^{[22]}$ & $1.251 \pm 0.006$ \\
\cline { 2 - 4 } & $\beta$ & $1.286^{[23]}$ & $1.268 \pm 0.006$ \\
\hline \multirow{2}{*}{ carbamazepine } & II & $1.235^{[24]}$ & $1.271 \pm 0.004$ \\
\cline { 2 - 4 } & III & $1.343^{[25]}$ & $1.320 \pm 0.004$ \\
\hline \multirow{2}{*}{ ibuprofen } & $S$ & $1.099^{[26]}$ & $1.091 \pm 0.001$ \\
\cline { 2 - 4 } & $R, S$ & $1.119^{[27]}$ & $1.108 \pm 0.001$ \\
\hline
\end{tabular}

\section{References}

[1] A. Gavezzotti, G. Filippini, J. Am. Chem. Soc. 1995, 117, 12299-12305.

[2] D. Giron, Thermochim. Acta 1995, 248, 1-59.

[3] L. Yu, J. Pharm. Sci. 1995, 84, 966-974.

[4] a) J. Bauer, S. Spanton, R. Henry, J. Quick, W. Dziki, W. Porter, J. Morris, Pharm. Res. 2001, 18, 859-866; b) L.-F. Huang, W.-Q. Tong, Adv. Drug Delivery Rev. 2004, 56, 321 334.

[5] a) L. Yu, J. Phys. Chem. A 2001, 106, 544-550; b) L. Yu, Acc. Chem. Res. 2010, 43, 1257-1266.

[6] R. M. Vrcelj, H. G. Gallagher, J. N. Sherwood, J. Am. Chem. Soc. 2001, 123, 2291-2295.

[7] a) M. D. Cohen, G. M. J. Schmidt, F. I. Sonntag, J. Chem. Soc. 1964, 2000-2013; b) T. Friščić, L. R. MacGillivray, Chem. Commun. 2009, 773-775. c) M. B. J. Atkinson, A. N. Sokolov, D.-K. Bučar, S. V. S. Mariappan, M. T. Mwangi, M. C. Tiedman, L. R. MacGillivray, Photochem. Photobiol. Sci. 2011, 10, 1384-1386.

[8] P. Li, I. W. Chen, J. E. Penner-Hahn, Phys. Rev. B: Condens. Matter 1993, 48, 1006310073.

[9] a) G. Barbarella, M. Zambianchi, L. Antolini, P. Ostoja, P. Maccagnani, A. Bongini, E. A. Marseglia, E. Tedesco, G. Gigli, R. Cingolani, J. Am. Chem. Soc. 1999, 121, 89208926; b) T. Siegrist, C. Kloc, J. H. Schön, B. Batlogg, R. C. Haddon, S. Berg, G. A. Thomas, Angew. Chem. Int. Ed. 2001, 40, 1732-1736.

[10] R. A. Heintz, H. Zhao, X. Ouyang, G. Grandinetti, J. Cowen, K. R. Dunbar, Inorg. Chem. 1998, 38, 144-156.

[11] S. Airaksinen, M. Karjalainen, E. Räsänen, J. Rantanen, J. Yliruusi, Int. J. Pharm. 2004, 276, 129-141.

[12] A. Nokhodchi, M. Maghsoodi, D. Hassan-Zadeh, M. Barzegar-Jalali, Powder Technol. 2007, 175, 73-81.

[13] a) Y. Kawashima, T. Niwa, H. Takeuchi, T. Hino, Y. Itoh, S. Furuyama, J. Pharm. Sci. 1991, 80, 472-478; b) A. Angermann, J. Töpfer, J. Mater. Sci. 2008, 43, 5123-5130.

[14] C. Sun, D. W. Grant, Pharm. Res. 2001, 18, 274-280.

[15] V. Niederwanger, F. Gozzo, U. J. Griesser, J. Pharm. Sci. 2009, 98, 1064-1074. 
[16] a) Y.-n. Xu, W. Y. Ching, Phys. Rev. B: Condens. Matter 1991, 44, 11048-11059; b) H. S. Nalwa, T. Saito, A. Kakuta, T. Iwayanagi, J. Phys. Chem. 1993, 97, 10515-10517; c) M. Brinkmann, G. Gadret, M. Muccini, C. Taliani, N. Masciocchi, A. Sironi, J. Am. Chem. Soc. 2000, 122, 5147-5157.

[17] a) S. R. Chemburkar, J. Bauer, K. Deming, H. Spiwek, K. Patel, J. Morris, R. Henry, S. Spanton, W. Dziki, W. Porter, J. Quick, P. Bauer, J. Donaubauer, B. A. Narayanan, M. Soldani, D. Riley, K. McFarland, Org. Process Res. Dev. 2000, 4, 413-417; b) J. Bauer, S. Spanton, R. Henry, J. Quick, W. Dziki, W. Porter, J. Morris, Pharmaceut Res 2001, 18, 859-866.

[18] W. Clegg, A. J. Blake, R. O. Gould, P. Main, Crystal Structure Analysis: Principles and Practice, 2002.

[19] K. A. Mirica, S. S. Shevkoplyas, S. T. Phillips, M. Gupta, G. M. Whitesides, J. Am. Chem. Soc. 2009, 131, 10049-10058.

[20] G. A. Stephenson, T. B. Borchardt, S. R. Byrn, J. Bowyer, C. A. Bunnell, S. V. Snorek, L. Yu, J. Pharm. Sci. 1995, 84, 1385-1386.

[21] P. McArdle, Y. Hu, A. Lyons, R. Dark, CrystEngComm 2010, 12, 3119-3125.

[22] T.-J. Hsieh, C.-C. Su, C.-Y. Chen, C.-H. Liou, L.-H. Lu, J. Mol. Struct. 2005, 741, $193-$ 199.

[23] G. M. J. Schmidt, J. Chem. Soc. 1964, 2014-2021.

[24] M. M. J. Lowes, M. R. Caira, A. P. Lotter, J. G. D. Van Watt, J. Pharm. Sci. 1987, 76, 744-752.

[25] a) J. N. Lisgarten, R. A. Palmer, J. W. Saldanha, J. Chem. Crystallogr. 1989, 19, 641649; b) V. L. Himes, A. D. Mighell, W. H. De Camp, Acta Crystallogr., Sect. B: Struct. Sci 1981, 37, 2242-2245.

[26] A. A. Freer, J. M. Bunyan, N. Shankland, D. B. Sheen, Acta Crystallogr., Sect. C: Cryst. Struct. Commun. 1993, 49, 1378-1380.

[27] J. F. Cryst. Struct. Commun.McConnell, Cryst. Struct. Commun. 1974, 3, 73-75. 